\title{
Influence of Sponsor's Management Style in Project Prioritization
}

\author{
Luciana Magalhães Girardin Pimentel-Rodrigues (D), Luciano Ferreira da Silva \\ Universidade Nove de Julho - UNINOVE (Brazil) \\ lucianamgirardin@gmail.com,lf_silvabr@yahoo.com.br
}

Received: November 2019

Accepted: July 2020

\section{Abstract:}

Purpose: The present study sought to understand how different sponsor management styles influence the prioritization of projects.

Design/methodology/approach: This empirical study used in-depth interviews with 11 executives to collect the data, and qualitative content analyses using theory and data-driven categories.

Findings: The results identified the emergence of the opportunistic management style and found evidence for the lack of strategic alignment in the project prioritization process.

Research limitations/implications: The lack of prioritization methods identified when comparing the project management styles and the number of project managers to interview as experts were the limitations of this study.

Practical implications: The analysis demonstrated that committees and post-project evaluations should be employed to mitigate failures, resulting from the management style of the sponsor, in the prioritization process.

Originality/value: The paper provides a critical perspective on the management styles of the sponsor in the context of project prioritization. It is important to highlight how different management styles of the sponsor result in different behaviors in the companies.

Keywords: management style, sponsor, project prioritization, project management, opportunistic behavior

\section{To cite this article:}

Pimentel-Rodrigues, L.M.G., \& Silva, L.F. (2020). Influence of sponsor's management style in project prioritization. Journal of Industrial Engineering and Management, 13(3), 430-450. https://doi.org/10.3926/jiem.3068

\section{Introduction}

Companies are constantly seeking to achieve their strategic objectives, which will guarantee their continuity and competitiveness in the market (Pinto, Nossa \& Teixeira, 2015; Chakkol, Selviaridis \& Finne, 2018), and effective project management styles help these companies realize the transformations needed to achieve these goals (Zimmer, Iata, Souza \& Cunha, 2017; Maylor \& Turner, 2017; Idler \& Spang, 2019). These necessary transformations, in terms of products and systems, structures and processes, are provided by project deliverables under a resource constraint scenario (Kerzner, 2017; Shenhar, 1998). Consequently, when a company does not have 
sufficient resources, such as personnel, finances or time, projects need to be prioritized through portfolio management for their development (Archer \& Ghasemzadeh, 1999; Dey, 2004; Kornfeld \& Kara, 2011).

Thus, when taking into account a contingency, due to the scarcity of resources, the projects need to be selected and prioritized. However, it is common for many companies to still accept projects even when they are operating beyond their capacity to develop them. One way a company can adjust the number of projects to be developed to its resource capacity is to use project prioritization methods. Indeed, many available prioritization methods can help companies make the best project decisions (Santhanam \& Kyparisis, 1995; Shollo, Constantiou \& Kreiner, 2015). However, it must be pointed out that no one method will meet all the needs of a company (Cooper, Edgett \& Kleinschmidt, 2000; Dey, 2004).

The present study assumed that sponsors can influence project selection and prioritization. A previous study by Malach-Pines, Dvir and Sadeh (2009) investigated the influence of personality traits on the success of projects, but the results did not validate the assumptions made and the authors recommended that qualitative studies needed to be conducted on this phenomenon. In this context, the sponsor, who is usually an executive, has to establish project priority, among other functions (Kerzner, 2017). It is important to emphasize that the role of the sponsor, as defined as an individual or a group of people, is to actively participate throughout the project cycle and to provide the resources and support for the project, program and /or portfolio (Englund, Bocero \& Bass, 2007; PMI, 2017; Zwikael, Meredith \& Smyrk, 2019).

Previous studies have associated the values, personal interests and behavior patterns of the sponsor with their managerial style (Morgan, 2011; Olmedo-Cifuentes \& Martínez-León, 2014), and this style influences the processes and behavior of the company. These behavioral aspects characterize management styles. Furthermore, while there is a plethora of management styles, an effective style depends on the specific situation and environment (Hersey \& Blanchard, 2014).

To provide greater clarity about the different management styles presented in the literature, in this study we mapped the following styles: autocrat, bureaucrat, democrat, innovator, negotiator and technocrat (Driver, Brousseau \& Hunsaker, 1998; French \& Raven, 1959; Gemmill \& Thamhain, 1973; Hodgetts, 1968; Kirton, 1976; Lewis, Welsh, Dehler \& Green, 2002; Morgan, 2011; Olmedo-Cifuentes \& Martínez-León, 2014; Shenhar, 1998). This approach sought to overcome the lack of in-depth investigations related to the influence of different sponsor management styles on project prioritization. By filling in this gap in knowledge the top management of companies will be able to act more effectively. Moreover, it has also been suggested that the lack of information about the benefits of the proper management style makes executives more reluctant to adopt different management styles (Tsai, Leu, Liu, Lin \& Shaw, 2010; Kloppenborg, Tesch \& Manolis, 2014). This is relevant because adapting management styles to the most diverse situations promotes greater effectiveness in their functions (Hersey \& Blanchard, 2014; Müller \& Turner, 2007; Tsai et al., 2010; Tabassi, Abdullah \& Bryde, 2019). In this context, the present study sought to achieve the following objective: To understand how different sponsor management styles influence project prioritization.

Based on reliable observations on the use of different management styles, Hersey and Blanchard (2014) argue that researchers can develop models that can predict which management style would be most appropriate for a specific situation. In other words, companies could determine which management style exerts more influence on the project prioritization process for that particular company's objectives.

The Standish Group (2014) showed that increasing the skills of the project sponsors improved information system (IS) project success rates from $29 \%$ in 2004 to 39\% in 2012. It has also been proposed by Tsai et al. (2010), Tabassi et al. (2019) and Cha and Maytorena-Sanchez (2019) that the main competences and capacities of the sponsors favor the achievement of the strategic objectives of the company. Moreover, according to the Pulse survey (PMI, 2017), an actively engaged sponsor is more likely to achieve the strategic objectives of the company. Despite the evident relevance of the sponsor's role in project management success, it is necessary to study the influence the sponsor has in the early phases of project prioritization (Kloppenborg et al., 2014), which is precisely the gap that this study intends to fill. 


\section{Theoretical Background}

In this section, we will present a review of the literature on the strategic alignment of projects, prioritization of projects and the management styles of the sponsor.

\subsection{Strategic Alignment of Projects}

Projects and programs are essential for implementing the company's strategic objectives and companies must understand how the strategy is aligned with the business and project management (Morris \& Jamieson, 2005). Indeed, considering the objectives, it is possible to establish a link between the company's strategy and individual goals.

A decade ago, Turner (2009) proposed an analytical model for this situation, which is called "Cascading Objectives". As shown in Figure 1, there are levels of objectives that range from the company strategy to the individual objectives. The idea behind this model is that the goals of one management level will impact the goals of the subsequent level, which as a consequence makes it possible to visualize how people and projects influence the achievement of the strategic objectives of the company.

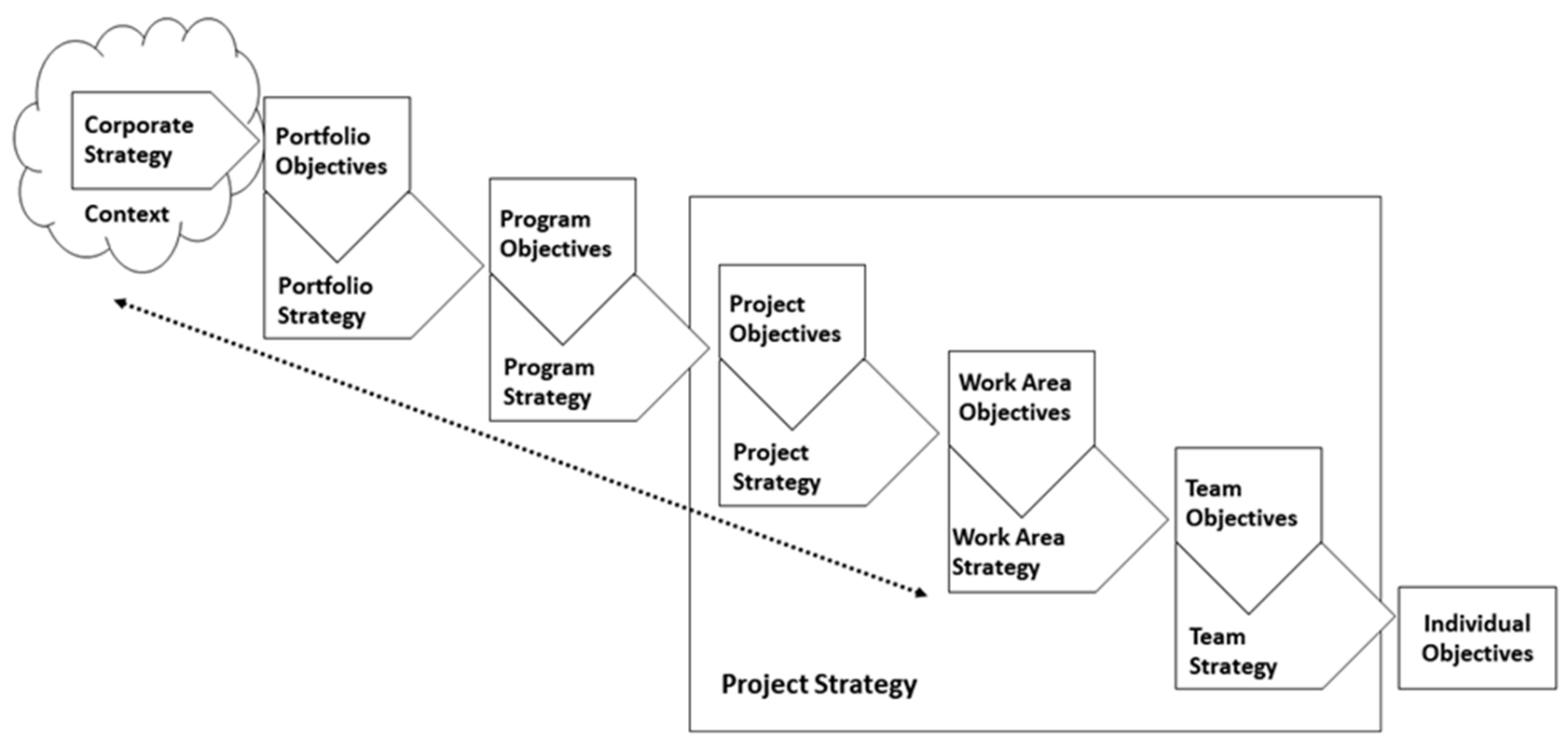

Figure 1. The cascading objectives (Turner, 2009: page 16)

By achieving each of the objectives, at different levels within a company, strategic alignment can be attained. The strategic alignment of the company is related to its ability to establish a strategic fit between its market position and the appropriate administrative structure to support its implementation (Henderson \& Venkatraman, 1993; Mintzberg, Ahlstrand \& Lampel, 2010). While the projects promote changes and are part of the strategic goals and the strategic alignment of the company, it is not clear how this unfolding and alignment of the company's goals to the projects takes place (Morris \& Jamieson, 2005; Pinto et al., 2015; Shenhar, Dvir, Levy \& Maltz, 2001; Zimmer et al., 2017).

Kornfeld and Kara (2011) and Petro and Gardiner (2015) point out that an investment and prioritization committee could align the project portfolio with the company's strategy, facilitate the use of organizational resources and maintain portfolio priorities. Moreover, the authors propose that, in this type of situation, there is theoretical evidence that project prioritization would be defended by these committees.

In this context, Kloppenborg et al. (2014) point out the successful implementation of the project is a priority since it is aligned with the company's strategic goals. Hence, people involved in project management have a pivotal role to play in ensuring that the company's strategic goals are met (Ramos, Mota \& Corrêa, 2016; Idler \& Spang, 2019). Therefore, it is important to understand that the project prioritization process, as part of portfolio management, is also influenced by the company's strategic alignment. 


\subsection{Prioritization of Projects}

The selection of projects requires choosing project proposals that meet the minimum requirements and strategic objectives of the company (Archer \& Ghasemzadeh, 1999; Kezner, 2017). As defined by Turner (2009), project prioritization is a classification from a set of criteria without exceeding the available resources. Thus, a project that was not prioritized at the moment might be so in the future. To reinforce the division in the prioritization phase of projects, Figure 2 was developed.

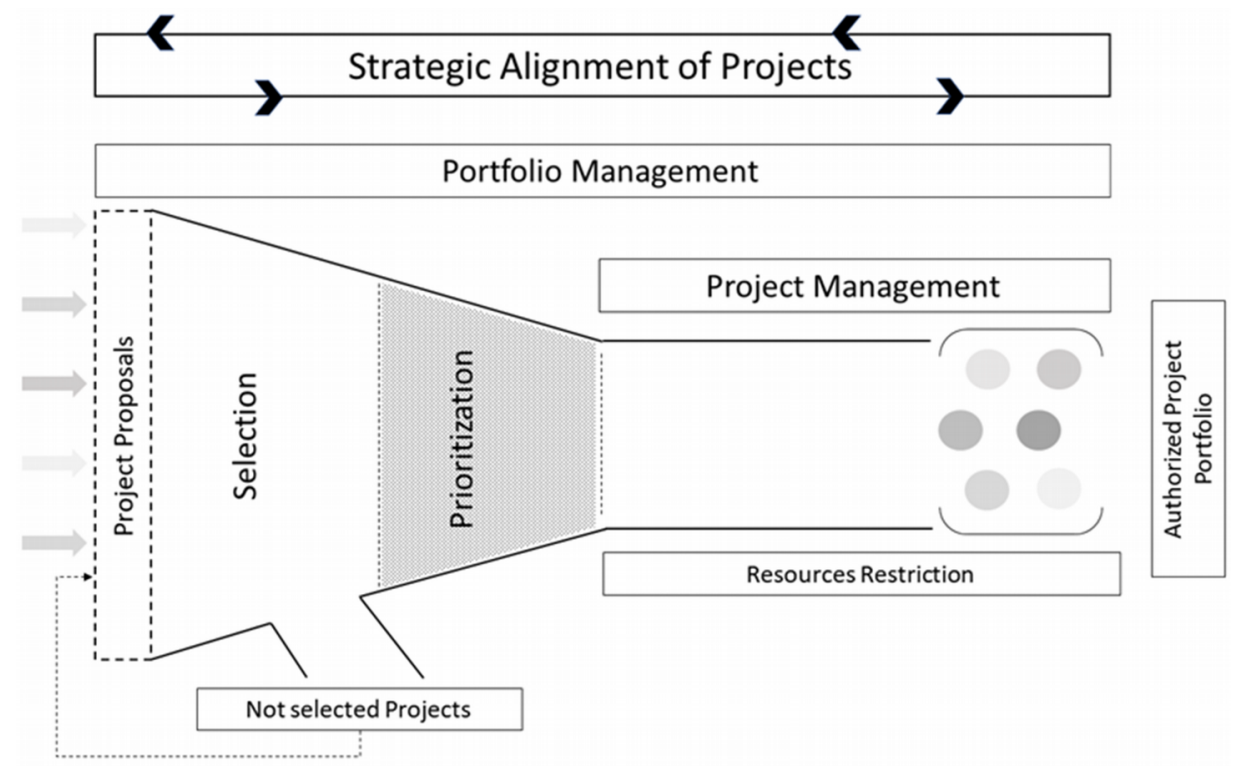

Figure 2. Portfolio management and its phases (Archer \& Ghasemzadeh, 1999; Morris \& Jamieson, 2005; Turner, 2009; Padovani, Carvalho \& Muscat, 2010)

As shown in Figure 2, portfolio management of projects involves different phases of analysis, selection, and prioritization. It should be stressed that when taking into account the resource restrictions and added value to the company, the methods employed to assist the manager's action must result in the formalization of an authorized and balanced project portfolio (Morris \& Jamieson, 2005; Padovani et al., 2010).

Another important point is that the overall goal of project prioritization methods is to develop approaches that companies can use to allocate a limited number of resources to a portfolio of competing projects and to balance the value and risk of the project so that it can be aligned with the company's strategy (Bardhan, Kauffman \& Naranpanawe, 2010). Along these lines, it is up to the executives to ensure that the selection of the projects in the portfolio is in line with the strategies of the company (Karhade, Shaw \& Subramanyam, 2015). Therefore, the selection criteria should not only choose the projects in the portfolio but also prioritize them (Padovani et al., 2010; Kornfeld \& Kara, 2011; Maylor \& Turner, 2017). In this sense, the selection criteria are essential to portfolio management.

Before selecting projects that will be included in the portfolio, companies collect information about the project proposals, and divide them into groups, so that the proposals can be compared using a single set of criteria defined by the decision-makers (Greiner, Fowler, Shunk, Carlyle \& McNutt, 2003; Shenhar \& Dvir, 2010). Such criteria may include financial values, scores for non-monetary factors and/or the strategic alignment of the company (Cooper, Easingwood, Edgett, Kleinschmidt \& Storey, 1994; Greiner et al., 2003).

Although many methods are available to companies, we found that there is a dissonance between the prescriptions and the prioritization embodied. For example, Shollo et al. (2015) shed light on the fact that the literature is predominantly characterized by a normative discourse that promotes a variety of techniques and methods. However, the authors also indicate that there is a misunderstanding about the application of proposed models to real-life complexities. 
In this sense, the successful implementation of these techniques often depends on some factors such as the type of decision, availability of project information, availability of resources during the decision-making process, understanding of the method and the perception of the decision-maker (Greiner et al., 2003; Maylor \& Turner, 2017). In the latter case, which is about the decision-maker, this can be influenced by the sponsor. Thus, we must understand the role of the sponsor in the prioritization of projects.

\subsection{Project Management Styles of the Sponsors}

A sponsor is a person or group that actively provides the resources and support for the project, program, or portfolio, and is responsible for the initiation and success of the project (Englund et al., 2007; PMI 2017). Depending on the phase of the project, the role of the sponsor can assume different dimensions. For example, during the initial stages, the sponsor advises the project manager on how to execute the project and establishes the priority of the project (Kerzner, 2017). We should clarify that the sponsors studied in this research are from the contracting party of the project.

In addition to the technical skills, the sponsor should also know how to deal with people within the company (Chandler \& Thomas, 2015; Englund et al., 2007; Cha \& Maytorena-Sanchez, 2019). In this context, knowing how to communicate with the stakeholders is a relevant role of the sponsor, since the company benefits when a good relationship with the stakeholders is established (Kloppenborg \& Tesch, 2015).

As the project moves to more advanced stages of development, the role of the sponsor is no longer limited to providing resources and financial support, because the sponsor takes on the responsibility for the strategic alignment of the project (Chandler \& Thomas, 2015). In this sense, the role of the sponsor as a manager is expanded, since the projects allow the company to achieve its strategic objectives.

Management is responsible for predicting, planning, organizing, commanding, coordinating and controlling through responsibilities, tasks and discipline (Drucker \& Maciariello, 2008). Leadership, in turn, is the process of intentionally influencing the activities of an individual or a group of individuals to achieve an objective in a specific situation (Bergamini, 1994; Turner, Müller \& Dulewicz, 2009; Hersey \& Blanchard, 2014).

Thus, since management and leadership are presented as distinct concepts (Turner et al., 2009; Vieira \& Costa, 2013), we chose to adopt the term management in this research. It is important to point out that the concept of management is associated with a sponsor's position since this person performs tasks and has certain responsibilities. Importantly, the sponsor, as well as the manager, actively influence the success of the company through project development (Kloppenborg et al., 2014; Zhu, Wang, Yu, Müller \& Sun, 2019).

The competencies of the sponsor vary according to the projects, management styles, and even companies. Thus, style management, attitude, and practice should be tailored to a specific project type (Shenhar, 1998). Moreover, each type of project may require certain individual characteristics, especially in projects that are constantly changing due to high levels of complexity and uncertainty (Xia \& Lee, 2005).

Notably, management styles are characterized by learned habits, ways of thinking and behaving, that generate a set of actions and describe the attributes of an individual (Driver et al., 1998; Lewis et al., 2002). Indeed, the way the project is developed and moves forward is related to the sponsor's interests, goals, values and expectations, as well as other orientations and inclinations (Morgan, 2011). In this sense, the management styles of the sponsor may stimulate or inhibit project prioritization and development.

It has been reported that some executives develop a particular management style in an attempt to achieve desired goals (Turner et al., 2009; Tsai et al., 2010). However, Hersey and Blanchard (2014) affirm that there is a greater tendency to train people in different management styles than to adapt behaviors to diverse situations. On the other hand, Gregory and Keil (2014) and Ramos et al. (2016) state that the cognitive and behavioral limitations of individuals usually results in a single style that is associated with individual beliefs and abilities.

Concerning project portfolio management, sponsors may need to adapt their management style regularly, or even consider different styles to achieve the goals of the company (Taskinen \& Smeds, 1999; Gregory \& Keil, 2014). Indeed, identifying the management style that is most compatible with the context, especially in the initial phase of 
portfolio management, such as the prioritization of projects, is essential (Ramos et al., 2016). Table 1 provides greater clarity about the different styles of management.

\begin{tabular}{|l|l|l|}
\hline \multicolumn{1}{|c|}{ Styles } & \multicolumn{1}{|c|}{ Description } & \multicolumn{1}{c|}{ Authors } \\
\hline Autocratic style & $\begin{array}{l}\text { Makes use of formal controls and hierarchical organization. } \\
\text { It is more incisive and task-oriented. Gets support because it } \\
\text { is perceived as the executive issuing the orders. They are } \\
\text { concerned about the methods to be used and the expected } \\
\text { results. }\end{array}$ & $\begin{array}{l}\text { Driver et al., 1998; French \& Raven, } \\
\text { 1959; Gemmill \& Thamhain, 1973; } \\
\text { Hodgetts, 1968; Morgan, 2011; } \\
\text { Olmedo-Cifuentes \& Martínez-León, } \\
\text { 2014 }\end{array}$ \\
\hline Bureaucratic Style & $\begin{array}{l}\text { Authority is exercised through the use of publications that } \\
\text { establish rules and guide the use of organizational activity. } \\
\text { The power and responsibility are related to the knowledge } \\
\text { and use of rules. }\end{array}$ & $\begin{array}{l}\text { Kirton, 1976; Lewis et al., 2002; } \\
\text { Morgan, 2011 }\end{array}$ \\
\hline Democrat style & $\begin{array}{l}\text { It is more democratic and focused on their relationship with } \\
\text { people. Analyzes problems in different ways, and decisions } \\
\text { are usually based on group discussions. }\end{array}$ & $\begin{array}{l}\text { Driver et al., 1998; Hodgetts, 1968; } \\
\text { Olmedo-Cifuentes \& Martínez-León, } \\
\text { 2014; Lewis et al., 2002; Morgan, 2011; } \\
\text { Shenhar, 1998 }\end{array}$ \\
\hline Innovative style & $\begin{array}{l}\text { A controller in unstructured situations. They have difficulties } \\
\text { maintaining group cohesion but provide the dynamics to lead } \\
\text { to radical periodic changes. }\end{array}$ & $\begin{array}{l}\text { Kirton, 1976; Kang, Solomon \& Choi, } \\
\text { 2015 }\end{array}$ \\
\hline Negotiator Style & $\begin{array}{l}\text { Gets support because he/she is perceived as the executive } \\
\text { capable of distributing organizational rewards. }\end{array}$ & $\begin{array}{l}\text { French \& Raven, 1959; Gemmill \& } \\
\text { Thamhain, 1973 }\end{array}$ \\
\hline Technocrat style & $\begin{array}{l}\text { Power and responsibility are linked to technical knowledge, } \\
\text { exercising greater influence in partner areas of the company } \\
\text { rather than in their subordinates. }\end{array}$ & $\begin{array}{l}\text { French \& Raven, 1959; Gemmill \& } \\
\text { Thamhain, 1973; Morgan, 2011; } \\
\text { Shenhar, 1998 }\end{array}$ \\
\hline
\end{tabular}

Table 1. Management Styles

The autocratic style is characterized by the practice of order management and is task-oriented (Gemmill \& Thamhain, 1973; Olmedo-Cifuentes \& Martínez-León, 2014). The bureaucratic style is related to the level of knowledge, the use of rules, method, discipline, and the legal form of administration, thus authority is exercised through the written word (Kirton, 1976; Morgan, 2011). The democratic style is characterized by the possibility of broad team participation, the freedom to challenge ideas, and problem-solving in a collaborative way (Lewis et al. 2002; Wilson, Bhakoo \& Samson, 2018). This style manifests itself through representative forms of management in which several executives are formally represented in the decision-making processes (Bergamini, 1994; Morgan, 2011). The innovative style does not usually favor team participation and can threaten the cohesion and cooperation of the group, sometimes even challenging the rules (Kirton, 1976; Kang et al., 2015). The negotiator style leverages the possibility that the individuals will receive organizational rewards to win support (French \& Raven, 1959). Finally, the technocratic style presented by Morgan (2011) reinforces that technical knowledge influences power and responsibility.

Through these examples, it becomes evident that the behavior of sponsor characterizes the different management styles (Driver et al., 1998; Taskinen \& Smeds, 1999; Lewis et al., 2002). Indeed, the efficient and appropriate use of these management styles can promote good relationships between the sponsors and the people involved in the prioritization of projects, consequently resulting in greater strategic alignment (Kloppenborg \& Tesch, 2015; Turner, 2009). It is for this reason that it is important to understand how these different management styles are associated with the project prioritization process and how each can help the company achieve its strategic objectives.

\section{Research Methodology}

For the present study, we opted to adopt a qualitative approach because it uses a set of procedures to understand and represent the meaning that individuals or groups attribute to a social problem (Creswell, 2010). Herein, the 
qualitative approach allowed us to explore the intersubjectivity of the interviewees' discourses about the prioritization of projects and the influence of the management style of the sponsor in this process. The methodological procedures used were selected based on a constructivist orientation (Lincoln \& Guba, 1985), and this influenced both the application of the data collection techniques and the analysis of the data because to meet the objective of this research we seek closer proximity to the phenomenon observed (Bêrni \& Fernandez, 2012).

Table 2 presents a summary of the profiles of the interviewees and the way each interview was conducted.

\begin{tabular}{|c|c|c|}
\hline Interviewed & Description & Interview condition \\
\hline $\begin{array}{l}\text { Interviewee } 1 \\
\text { (E1) }\end{array}$ & $\begin{array}{l}\text { Manager with experience in the Agribusiness Industry and } \\
\text { expertise in the aviation industry, where she worked on several } \\
\text { projects. }\end{array}$ & $\begin{array}{l}\text { The interview was conducted by } \\
\text { electronic means. It took around } 60 \\
\text { minutes and was recorded for subsequent } \\
\text { analysis. }\end{array}$ \\
\hline $\begin{array}{l}\text { Interviewee } 2 \\
\text { (E2) }\end{array}$ & $\begin{array}{l}\text { Manager with experience in Telecommunications and } \\
\text { Information Technology. She worked on projects involving } \\
\text { the implementation of new systems. }\end{array}$ & $\begin{array}{l}\text { The interview was conducted by } \\
\text { electronic means. It took around } 20 \\
\text { minutes and was recorded for subsequent } \\
\text { analysis. }\end{array}$ \\
\hline $\begin{array}{l}\text { Interviewee } 3 \\
\text { (E3) }\end{array}$ & $\begin{array}{l}\text { Manager with experience in the aviation industry. He was } \\
\text { responsible for conducting the operational board, where he } \\
\text { sponsored several systems implementation projects. }\end{array}$ & $\begin{array}{l}\text { The interview took place in a private } \\
\text { setting. It took around } 40 \text { minutes and } \\
\text { was recorded for subsequent analysis. }\end{array}$ \\
\hline $\begin{array}{l}\text { Interviewee } 4 \\
\text { (E4) }\end{array}$ & $\begin{array}{l}\text { Manager with substantial experience in the technology } \\
\text { industry. In his career, he worked on complex projects in the } \\
\text { technology area, following all phases of the projects. }\end{array}$ & $\begin{array}{l}\text { The interview took place in a private } \\
\text { setting. It took around } 30 \text { minutes and } \\
\text { was recorded for subsequent analysis. }\end{array}$ \\
\hline $\begin{array}{l}\text { Interviewee } 5 \\
\text { (E5) }\end{array}$ & $\begin{array}{l}\text { Manager and researcher in the area of project management. } \\
\text { He has experience in the agribusiness and technology } \\
\text { industries. He has been involved in the implementation of } \\
\text { methodologies for portfolio management. }\end{array}$ & $\begin{array}{l}\text { The interview took place at the company } \\
\text { where the interviewee works, took } \\
\text { around } 25 \text { minutes and was recorded for } \\
\text { subsequent analysis. }\end{array}$ \\
\hline $\begin{array}{l}\text { Interviewee } 6 \\
\text { (E6) }\end{array}$ & $\begin{array}{l}\text { prioritization of projects. He has experienc } \\
\text { management in the retail, technology, and }\end{array}$ & $\begin{array}{l}\text { The interview took place in a private } \\
\text { setting. It took around } 30 \text { minutes and } \\
\text { was recorded for subsequent analysis. }\end{array}$ \\
\hline $\begin{array}{l}\text { Interviewee } 7 \\
\text { (E7) }\end{array}$ & $\begin{array}{l}\text { Manager with experience in the aviation industry in the area } \\
\text { of services, where he sponsored several systems } \\
\text { implementation projects. }\end{array}$ & $\begin{array}{l}\text { The interview took place in a private } \\
\text { setting. It took around } 30 \text { minutes and } \\
\text { was recorded for subsequent analysis. }\end{array}$ \\
\hline $\begin{array}{l}\text { Interviewee } 8 \\
\text { (E8) }\end{array}$ & $\begin{array}{l}\text { Manager with expertise in the technology area in the chemical } \\
\text { and automotive industries. He participated in systems } \\
\text { development and implementation projects. }\end{array}$ & $\begin{array}{l}\text { The interview was conducted by } \\
\text { electronic means. It took around } 45 \\
\text { minutes and was recorded for subsequent } \\
\text { analysis. }\end{array}$ \\
\hline $\begin{array}{l}\text { Interviewee } 9 \\
\text { (E9) }\end{array}$ & $\begin{array}{l}\text { Manager with experience in the automotive, technology, } \\
\text { aviation, and insurance industries, where she worked in } \\
\text { systems development and deployment projects. }\end{array}$ & $\begin{array}{l}\text { The interview was conducted by phone. } \\
\text { It took about } 25 \text { minutes and was } \\
\text { recorded for subsequent analysis. }\end{array}$ \\
\hline $\begin{array}{l}\text { Interviewee } 10 \\
\text { (E10) }\end{array}$ & $\begin{array}{l}\text { Manager with experience in the packaging industry, where he } \\
\text { participated in systems implementation projects. }\end{array}$ & $\begin{array}{l}\text { The interview was conducted by } \\
\text { electronic means. It took around } 35 \\
\text { minutes and was recorded for subsequent } \\
\text { analysis. }\end{array}$ \\
\hline $\begin{array}{l}\text { Interviewee } 11 \\
\text { (E11) }\end{array}$ & $\begin{array}{l}\text { Manager and researcher with experience in the airline industry. } \\
\text { He was responsible for conducting the operational board, } \\
\text { where he sponsored several projects for the implementation } \\
\text { and development of systems. }\end{array}$ & $\begin{array}{l}\text { The interview was conducted by } \\
\text { electronic means. It took around } 20 \\
\text { minutes and was recorded for subsequent } \\
\text { analysis. }\end{array}$ \\
\hline
\end{tabular}

Table 2. Summary of interview information

The employed data collection process involved in-depth interviews, which was adequate for understanding the reality of the interviewees. This process was guided by a directed conversation focusing on the relationship between 
the management styles of the sponsors and the prioritization of projects. Thus, the goal of the interview was to identify patterns of behavior, and use an inductive process based on the development of categories or themes presented by the interviewees that allowed for analytical generalizations, or even the construction of theories (Creswell, 2010). It is also worth noting that a deductive process, based on the managerial styles presented in Table 1, was employed to categorize the responses of the interviewees. The categories were constructed using datadriven and theory-driven perspectives, according to the recommendations of Charmaz (2006).

\subsection{Interviews and Data Collection}

As proposed by Creswell (2010), the intentional selection of the interviewees in qualitative research provides the researcher with a better understanding of the problem (Creswell, 2010). Therefore, we stress that some criteria were established for the composition of the sample, which was composed of managers with experience in prioritizing projects. Moreover, these managers played the role of a sponsor or followed the prioritization process of projects in which they observed the management style of the sponsor.

The interviews were applied in person, through electronic means or phone calls and were recorded for later analysis. In total 11 managers were selected and interviewed. Interviews were stopped when we achieved the theoretical data saturation, as indicated by Charmaz (2006). As explained by Silva, Godoi and Melo (2010), theoretical saturation is achieved when the explanatory gains of the phenomenon are almost non-existent when new analyses are carried out.

Concerning the interview questions, we did not opt for a structured questionnaire but rather engaged in a conversation in which the aim was to allow the interviewee to speak as much as possible about their professional experiences and observations. In other words, the interviewees were asked to make statements about the projects. Furthermore, the interviewer interventions were to inquire about the "how" or "why" related events or activities occurred (Silva et al., 2010). The guidelines for conducting the interviews was mainly based on the response to the following three items: i) the process of project prioritization and the methods used; ii) the role of the sponsor in the project prioritization process; iii) the management styles of the sponsor in the project prioritization process. The interviews were recorded, transcribed, and then imported into the Atlas.Ti qualitative data analysis software (Friese, 2012).

\subsection{Data Analysis}

The data analysis and discussion phase mainly follow a data-driven perspective. This type of perspective allows the researcher to start from the interview data for the construction of categories of analysis - codes (Charmaz, 2006; Saldaña, 2012). Herein, this process was performed based on the coding technique of Creswell (2010), which described a process of organizing the material and assigning labels of the categories highlighted with a term (code), and was based on the participant's actual language.

First, we performed the open encoding, which aims to recognize incidents, represented by passages, words, images, among others, and helps to answer the research problem. These first-order codes were grouped to establish relationships through axial coding. Based on the general framework constructed from the incidents and relating them hierarchically with other second-order codes, more abstract categories are obtained (Charmaz, 2006; Saldaña, 2012).

The analysis was also performed using the constant comparison technique, in which the coding and analysis activities are carried out in a concomitant and circular manner. Such a technique allows comings and goings to the research corpus for validation of the categories of analysis (Charmaz, 2006; Saldaña, 2012). This process follows a flow towards the research objectives and is not tied to the process linearly. Thus, as the theoretical sampling is increased (number of incidents found), the main elements, which are used to create more abstract categories, are constructed as well as their respective properties (Silva et al., 2010). The goal of this approach was to go beyond description and identification and come to complex theme connections, which is a characteristic of qualitative studies with a high degree of excellence (Creswell, 2010). Notably, the initial categories of analysis were developed from a theory-driven perspective. In this context, these categories represented the management styles and were constructed from the search and analysis of the theoretical reference. 
To identify the theoretical saturation in the collected information and to exhaust the search for new incidents by increasing the database, we implemented the "Codes-Primary Documents Table" and "co-occurrence" tests in the Atlas.Ti software (Friese, 2012). The former presents the frequencies of the codes in categories established in the analysis phase and the latter provides a report with the relationships between the codes and the categories constituted during the analysis.

The codes represent the reality of the sponsors in the project prioritization process, and the incidents correspond to the excerpts from the statements that express descriptions, examples, and other explanations. It should be pointed out that some extracted incidents contain more than one code, and these situations are referred to as co-occurrences. It is also worth mentioning that the use of Atlas.Ti was essential to perform this kind of analysis since this software allows us to relate the codes in their contexts and establish a co-occurrence coefficient, which is determined by the proximity or overlap of codes in the same context, that is, a segment of text selected and classified with the respective codes assigned to this segment.

As already alluded to, the relationship of the codes results in a coefficient that indicates the strength of the relationship between two codes (Friese, 2012). In general, the value of this coefficient is between 0 and 1 . Although the coefficient bears a striking similarity to statistical calculations, the analysis is done qualitatively and looks for behavior patterns in the discourses. This pattern is then validated by searching the responses of the respondents, or through other sources of evidence, only being recognized as valid when they are based on the data. As mentioned previously, this process utilizes categories built from the theory or categories that emerged from the data. This direction does not determine the strength of the code, but rather the contribution that a study can generate since categories that arise from the data can be considered, once validated, theoretical contributions.

After applying the co-occurrence analysis, every positive value indicates that a relationship between the codes exists, and this ratio may be more substantial with higher values. In contrast, a value of zero suggests that there is no apparent relationship between the codes. Regardless of the values, the relationships between codes, need to be analyzed based on the frequency of incidents. It is important to emphasize that in this type of research we are not searching for quantity, but rather patterns of behavior in the data.

\section{Results and Discussion}

Based on the data collected in the interviews, in this section, we present the results on the themes of sponsor management styles and the project prioritization process.

\subsection{Interview Analysis}

The categories of analysis were initially constructed by reading, reflection, and interpretation of the sources of evidence, which were mainly represented by the interviews. The managerial style categories emerged almost entirely via the theory-driven perspective, or from theoretical assumptions previously used. However, some categories emerged from the data-driven perspective (interviews), which means that these categories were constructed from the discourses (Grounded).

The relationships between the codes obtained from the co-occurrence analysis are summarized in Table 3. As previously mentioned, these coefficients are similar to correlation coefficients in statistics and are indicative of the strength of the relationship between two codes (Friese, 2012).

In the columns of Table 3, the management styles raised initially in the literature as well as those observed in the interviews are presented, except for the opportunistic style, which only emerged from the analyses. In the rows of Table 3, the aspects that emerged from the analysis of the interviews are presented. The numbers in parentheses correspond to the number of times (frequency) that each category appeared in the discourse of the interviewees.

Although the coefficient is similar to statistical calculations, the goal of the analysis is to qualitatively identify patterns of behavior. This pattern is only validated when present in the interviewees' statements, or via other sources of evidence. Again, this process can utilize categories constructed from the theory or categories that emerged from the data. This direction does not determine the strength of code but the contribution that a study can generate since categories that arise from the data can be considered, once validated theoretical contributions. 


\begin{tabular}{|c|c|c|c|c|c|c|c|c|}
\hline & & \multicolumn{7}{|c|}{ SPONSOR'S MANAGEMENT STYLE } \\
\hline \multirow{6}{*}{ 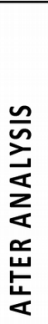 } & & \begin{tabular}{|c|}
$\begin{array}{c}\text { Autocrat Style } \\
(41)\end{array}$ \\
\end{tabular} & \begin{tabular}{|c|} 
Bureaucrat Style \\
$(8)$ \\
\end{tabular} & \begin{tabular}{|c|} 
Democratic Style \\
$(12)$
\end{tabular} & $\begin{array}{c}\text { Innovative Style } \\
\text { (6) }\end{array}$ & \begin{tabular}{|c|}
$\begin{array}{c}\text { Negotiating Style } \\
(73)\end{array}$ \\
\end{tabular} & $\begin{array}{c}\text { Opportunistic Style } \\
(10)\end{array}$ & $\begin{array}{c}\text { Technocrat Style } \\
(16)\end{array}$ \\
\hline & $\begin{array}{l}\text { Qualitative approach } \\
\text { (7) }\end{array}$ & 0.00 & 0.07 & 0.00 & 0.00 & 0.01 & 0.00 & 0.00 \\
\hline & $\begin{array}{l}\text { Quantitative } \\
\text { Approach (26) }\end{array}$ & 0.00 & 0.10 & 0.00 & 0.00 & 0.00 & 0.00 & 0.02 \\
\hline & $\begin{array}{l}\text { Strategic Project } \\
\text { Alignment (67) } \\
\end{array}$ & 0.02 & 0.00 & 0.01 & 0.00 & 0.02 & 0.00 & 0.01 \\
\hline & \begin{tabular}{|l} 
Post-Project \\
Evaluation (18)
\end{tabular} & 0.05 & 0.00 & 0.00 & 0.04 & 0.01 & 0.04 & 0.00 \\
\hline & \begin{tabular}{|l} 
Investment \\
Committee (28)
\end{tabular} & 0.00 & 0.00 & 0.03 & 0.03 & 0.05 & 0.00 & 0.00 \\
\hline$\underset{n}{\stackrel{u}{E}}$ & $\begin{array}{l}\text { Lack of Strategic } \\
\text { Alignment (15) }\end{array}$ & 0.02 & 0.00 & 0.00 & 0.11 & 0.02 & 0.09 & 0.00 \\
\hline ㄴ & \begin{tabular}{|l|} 
Lack of Formal \\
Project Prioritization \\
Process (29)
\end{tabular} & 0.03 & 0 & 0.03 & 0.00 & 0.01 & 0.00 & 0.00 \\
\hline \multirow{8}{*}{ 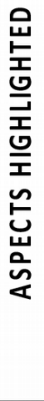 } & \begin{tabular}{|l|} 
Grupo de \\
patrocinadores (5)
\end{tabular} & 0.00 & 0.00 & 0.06 & 0.00 & 0.01 & 0.00 & 0.00 \\
\hline & $\begin{array}{l}\text { Non-prioritization of } \\
\text { projects }(10)\end{array}$ & 0.02 & 0.00 & 0.00 & 0.14 & 0.01 & 0.00 & 0.08 \\
\hline & Political Action (11) & 0.00 & 0.00 & 0.00 & 0.00 & 0.08 & 0.05 & 0.04 \\
\hline & \begin{tabular}{|l} 
Top Down Projects \\
Prioritization (39)
\end{tabular} & 0.10 & 0.00 & 0.00 & 0.00 & 0.00 & 0.00 & 0.00 \\
\hline & \begin{tabular}{|l|} 
Project Prioritization \\
Process (31) \\
\end{tabular} & 0.03 & 0.00 & 0.00 & 0.00 & 0.01 & 0.00 & 0.00 \\
\hline & \begin{tabular}{|l|} 
Prioritized Project \\
$(7)$
\end{tabular} & 0.02 & 0.00 & 0.00 & 0.00 & 0.00 & 0.00 & 0.10 \\
\hline & $\begin{array}{l}\text { Strategic Projects } \\
(4)\end{array}$ & 0.00 & 0.00 & 0.00 & 0.00 & 0.00 & 0.00 & 0.00 \\
\hline & Financial return (23) & 0.02 & 0.19 & 0.00 & 0.00 & 0.00 & 0.00 & 0.00 \\
\hline
\end{tabular}

Table 3. Co-occurrence of Management styles and Aspects Highlighted to Styles After Analysis

As mentioned previously, after applying the co-occurrence analysis, positive values confirm that a relationship exists between the codes, and the higher the value the stronger the relationship. In contrast, when the value is zero there is no apparent relationship between these respective codes. Regardless of the value, all connections between codes must be analyzed. Another important piece of information presented in Table 3 is the frequency of each code and is shown in brackets.

From the analysis described above, and from other reports generated by the Atlas.Ti software, we then compared the relationships and read the incidents critically and reflexively. By doing so we were able to identify arguments that are presented here. One particularly relevant aspect revealed by this analytical process is the ability to capture the patterns in the statements from the interviewees and demonstrate the results from these discourses.

Initially, we observed that the project prioritization process, as represented by the code "Project Prioritization Process", is related to the code "Strategic Project Alignment". For example, during the discourse interviewee, E1 stated "I think the important thing before the prioritization is the definition of projects within the company. I think it has to be very much in line with its strategy"; and interviewee E4 stated, "I would say that first, you have to capture all the demands and have in parallel a clear strategy [...]". Both of these statements reinforce the company's strategy, with the code "Strategic Project Alignment" being an essential baseline factor for aligning the company's strategic objectives with the projects that will be developed. This observation is consistent with that of Morris and Jamieson (2005), who explained that projects are a means for implementing the strategy.

Shollo et al. (2015) stated that the project prioritization process promotes the effective management of human and financial resources when resources are limited. In this sense, the prioritization process organizes demands versus available resources so as not to overburden them, or impact project results. As stated by E4, "So today the prioritization clashes head-on with the goals of the company, with what it has in terms of ambition. And the prioritization helps us know when to say yes or no with enough quality".

The code "Strategic Project Alignment" is associated with a high incidence to the code "Quantitative Approach", which represents a quantitative analysis for the prioritization of projects through the code "Financial Return". The search for quantitative methods or evaluations demonstrates the search for rationality in decision-making project prioritization. The code "Financial Return" is cited as a premise in some project prioritization processes, and sponsors that utilize the bureaucratic style, as denoted by the code "Bureaucratic Style", more naturally meet 
the standards required by the process. This is because this management style fulfills the premises and adapt to the rules pre-established in the prioritization process, consequently transferring more authority to the prioritization process. This is confirmed in the discourses of interviewees E2 and E6 who state: "[...] for some years we have observed in Brazil that what is called strategic planning, is, in fact, the highest financial return in the shortest possible time"; and "But it's the same thing, they prioritized the strategy of the company to yield a high return".

However, the interviewees showed a superficial knowledge about the project prioritization methods, mostly because many companies do not use any standardized or formal method of project prioritization, as evidenced in the discourses of interviewees E2 and E5: "I do not remember any formal pre-established project prioritization process. [...] So this may be a feature of this IT industry, this lack of prioritization methodology"; and "So one might end up saying: look, set a 15-minute meeting with the president to defend that [...]. It's just a very informal business. No methodology at all". This finding supports the position of Shollo et al. (2015) who stated that the existence of a normative discourse to promote a variety of methods of project prioritization requires the application of the models in real-life companies.

The code "Lack of Strategic Alignment" is cited with high frequency by the interviewees, demonstrating a common situation in the companies. For example, interviewees E5 and E7 said: "[...] the difficulty that the entire company has with strategic direction is what to do with prioritizing. For [what I remember], there was no place I went through that this [strategy] was super clear, super well defined..."; and "So we lack a great deal of internal planning for jointly defining the real priorities of the business".

Shenhar et al. (2001) affirm that the lack of strategic alignment ends up benefiting projects without relevance, which becomes a significant risk for the company. Such a scenario is confirmed in the discourse of the interviewee E7: "Now is this a [project] that is necessary at the moment that we are living? Other things have more priority. But at the same time, we do not have [other more important projects]".

Therefore, it is noticeable in the discourses of the interviewees that companies that do not seek a strategic alignment face difficulties in prioritizing projects. Another point observed in this type of situation, and that presents a reality without the project prioritization process, is that all hierarchical levels seek projects without taking into consideration the needs of the company. Since business objectives are not cascaded up to individual objectives, as shown in Figure 1, the employees do not know if what they are demanding is necessary for the company. The reality of applied cascade levels is also represented in the discourse of the interviewee E4: "[...] I think today without having a clear strategy of where the company wants to go and how it wants to cascade these needs to become objectives of the departments, strategic goals, derive personal goals from each employee, it needs to have a clear strategy".

Since the strategic objectives of the company are not known, it becomes more challenging to choose the projects that effectively benefit the company. In this sense, the interviewees mentioned that investment committees are a valuable resource in the strategic alignment of projects. Along these lines, Petro and Gardiner (2015) emphasized that investment committees support companies by selecting projects and ensuring strategic alignment, which is confirmed by the discourses of interviewees E1 and E7 who stated: "So in the same way that I want to present, another department also wants it. And who is there will decide what is most important for the company"; and "Because there was a committee there, all departments participated [...]. All projects of all areas are feasible to prioritize, and hence a ranking is included". Indeed, the relationship between the "Investment Committee" and "Project Prioritization Process" is confirmed. Thus, the consensual decision of the investment committee allows for projects to be selected and prioritized based on the defense of the project by the sponsor and the strategic alignment of the company.

The influence of the sponsor is confirmed by the interviewees as a differential attribute to achieve the desired project prioritization. However, this ability to influence can become a significant risk to companies with no clear objectives, since the sponsor can defend projects based on their unique understanding, and analysis without considering the needs of the company. In this way, the investment committee was mentioned as a way to mitigate the negative influence exerted by the sponsor. For example, interviewee E5 stated "Because you have a committee 
of 10,15 people, for example, the chance that the guy can influence the 15 is tough. So, I think the purpose of the committee was precisely this" and E7 said "all areas participated and had definitions together. All projects of all areas that for the company are feasible to prioritize, and hence a ranking is included".

Additionally, another attitude pointed out by Chandler and Thomas (2015), Englund et al. (2007) and Kloppenborg and Tesch (2015), and confirmed by interviews, is the ability of the sponsor to know how to handle and speak with people, and be able to understand the expectations of the people involved in the project, such as the stakeholders and decision-makers. The interviewees reinforce how this ability can favor the sponsors in the project prioritization process. Respondents stated in a consensual way that the sponsor's management style could support them in the prioritization of the projects, and the need of the sponsor to adapt their management style depending on the context. The discourses from respondents E3 and E9 corroborate this relationship when they respectively stated: "A project today is no longer your project. You develop the project for others. If you do not have this ability, your project does not go forward. You may need to change the way you approach your project to try to approve it at least partially", and "So depending on his style, on his ability to demonstrate this, he may be more or less successful".

The fact evidenced here about effective project prioritization and management style is consistent with theorists such as Ramos et al. (2016) who agree with the influence exercised by management on human performance. It was also possible to confirm that sponsors can adapt their behaviors to the most diverse situations, an observation previously exposed by Gregory and Keil (2014) and Hersey and Blanchard (2014). However, it is not clear in the interviews if this is the result of training. On the other hand, when this adaptation does not happen, it is unknown if it is due to cognitive limitations. Therefore, since the sponsor's management style exerts an influence on the project prioritization process, it is worth highlighting how this relationship occurs.

It was found that the code "Top-Down Projects Prioritization" has a strong relationship with the "Autocratic Style" and "Lack of Formal Prioritization of Projects" codes. Thus, it can be inferred that companies lacking a formal prioritization process tend to favor the autocratic style by top-down project prioritization. In this type of a decision, some projects are prioritized in a particular way by the executives without any alignment with the project prioritization method, if it exists. The top-down project prioritization is reinforced by interviewees E2 and E7 when they stated: "And prioritization also occurs much more based on executive feeling, of the executive hierarchical layers than itself following a prioritization methodology"; and "[...] the board presents an idea. [The board] wants to implement such a thing. [...] It's a demand for us. [...] a series of things that no one thought, but as it came top-down, you have to implement it and soon".

Another critical aspect of the relationship mentioned above is that the autocratic style tends to impose its wish, meaning that the behavior is acceptable as long as it comes from the high hierarchical levels. On the other hand, if this manager occupies a mid-level position, he/she may not be able to influence the higher levels in project prioritization processes or take advantage of the negotiating style. Indeed, it is this type of situation that reinforces the idea behind this study, which is that the management style of the sponsor influences the prioritization of projects.

The code "Autocratic Style" was mentioned and related by the interviewees to the code "Post-Project Evaluation". This code means that the autocratic style is supported by companies that do not have a post-project evaluation. This scenario emerges in the discourses of respondents E3 and E5 when they said: "Today's top-down projects are based on [individual] goals and most do not support themselves" and "So the [non-validation] culture supports the autocratic [...]". As stated by Olmedo-Cifuentes and Martínez-León (2014), the prioritization of the desired project is imposed by sponsors with an autocratic style. However, since the promised project results are not validated in the end, there are no ways to prove the results, thus benefiting the precise controls of the sponsor.

Another relevant aspect observed in the analysis is that sponsors with the innovative style face difficulties in prioritizing projects in companies that do not have innovation as a strategy. This situation is confirmed by the relationship between the "Innovative Style" and the "Non-Prioritization of projects" codes. This is best corroborated by interviewees E1 and E11 whose professional backgrounds do not involve companies that focus on innovation. For example, E11 states “[...] there's always someone who has many ideas. Normally in prioritization, 
this guy ends up being behind because not everyone understands how his new idea works". Another relevant aspect in this style is the distancing of conventional metrics such as ROI, as confirmed in interviewee E1's discourse: "Sometimes the guy does a mega power plus presentation, super, but the guy is not part of the operation. The one who is the top executive sees things in a macro way. [...] Sometimes the guy sells a surreal idea that, if it works, would be great, but the company does not have the structure for that". In this way, unlike other occasions where financial rationality determines decisions, the innovative style has difficulty demonstrating its arguments and prioritizing projects in conservative scenarios.

The "Negotiator Style" code was associated with the code "Political Action". This means that the project deliverables are negotiated and shared with other areas so that the project is more likely to be prioritized. This fact is confirmed in the discourses of interviewees E3 and E4: "So when you talk about knowing how to do politics, it means you are seeking the marketing person saying: look I have a project here, and I will gain in savings, but you will gain in punctuality, let's embrace it together?"; and “[...] I think there are political issues. It's the same when you are going to define project scope; there is a lot of scope change within the project that you approve of having buy-in from some areas, regardless of what is the best for the company". Thus, even if there are procedures and rules to follow, the sponsor's negotiator style can gain support in their project through rewards. Interestingly, this same point of view was previously demonstrated in the studies of French and Raven (1959), Gemmill and Thamhain (1973), and Kirton (1976), in which they showed that the negotiating style of the sponsor can influence the process of prioritizing projects in companies in both formal and informal contexts.

However, it is important to emphasize that sponsors are not associated with a single management style, which contradicts the work of Gregory and Keil (2014) that stated, individuals, are limited to a unique management style. On the contrary, the negotiating style of the sponsor may be associated with the technocratic style, which means that the negotiation attributes can be related to the technical knowledge of the sponsor. We concur that this combination could facilitate project prioritization. This association is corroborated in the discourse of interviewees E1 and E7 when they said "When I mentioned the selection of the sponsor, knowing is not just the technical part. So, for example, if you want to do a project related to the behavior of sale, access, even the commercial part. There has to be a person who has influence, who knows people" and "Because if it is a person who knows the project and is willing to sell it, and has sufficient arguments to show that it is important, it will have a level of prioritization in the ranking".

The technocratic style of the sponsor is still considered a differentiated attribute since it is based on the ability to explain, through its technical knowledge, to bring more significant specifications and taking advantage over other styles in defense of their projects. This situation can be confirmed in the discourse of interviewee E11: "Because he knew exactly what he needed. He was able to hit the point of what he needed spot on, and maybe that somehow, in the prioritization meeting did what he wanted to appear as easier to do". In this sense, the technocratic style tends to facilitate the understanding of the prioritization process and happens mainly in situations where the project requires specific technical knowledge. This observation is in line with the work of Morgan (2011), who studied technical knowledge impact power and responsibility managers' competences (Technocratic). Thus, technical expertise as a source of power originates in a project context when it has clear and predictable methodologies, but would not be appropriate in situations that deal with innovation and unpredictability.

In some cases, the technocratic style of the sponsor may not get the project prioritized, which was confirmed by the relationship between the "Technocratic Style" and "Non-Prioritization of Projects" codes. Additionally, when interviewee E3 said "So we miss many projects because we consider only the technical part", this aspect of project prioritization is highlighted. This fact also confirms the position presented by Shenhar (1998), who cited that the sponsor's attitudes and practices need to adapt to the type of project and the environment. Thus, the sponsor needs to have the ability to adapt their style or lean towards one style more depending on the type of project and environment that will be defended.

The sponsor's democratic style is found in corporate initiatives through the creation of sponsorship groups and is evidenced by the relationship between the codes "Democratic Style" and "group of Sponsors". In the discourses of interviewees E4 and E8 where they state "So I prefer for the sponsor to be a committee rather than a single person, to avoid this indecisiveness" and "Usually the sponsors of the project are 4, or 5 people. So I bring in the 
person from TI, I bring in the person from the business, I bring a person from a functional area that's involved [for example: financial, logistics] and I bring a person in contact with the customer, in contact with the supplier, something like this, to counteract the customer's vision" also support this relationship. As stated by Olmedo-Cifuentes and Martínez-León (2014) with this type of approach, decisions are based on group discussions, which guarantees a more comprehensive but sometimes more time-consuming final decision.

One relevant piece of evidence that came from analyzing the data is the association between the opportunistic style and ambition, vanity, and personal interests. This style is mainly observed in environments where there is no clear strategic alignment and is confirmed by the relationship between the codes "Opportunistic Style" and "Lack of Strategic Alignment". Such behavior was evidenced in the discourses of interviewees E1 and E4, who stated: "Now if this is a departmentalized organization where those giving more should lead [...] Like the Chamber of Deputies [...] You approve of my project and I approve of yours. Regardless of whether it will have a benefit or not" and "But not necessarily the priority reflects what a priority for the company itself is, it involves [...] projects are very attractive for growth, for power, for influence". The sponsor with an opportunistic style can prioritize a project for his benefit, disregarding the interests of the company.

As explained in the Transaction Cost Theory (Williamson, 1996), the opportunistic sponsor can be understood as the individual who tries to optimize his/her position at the expense of others. In the opportunist behavior, individual interests take priority over organizational interests. It has also been cited that opportunistic behavior is often associated with asymmetric information conditions (Ketokivi \& Mahoney, 2016). The sponsor with opportunistic style also uses the exchange to benefit, which was evidenced in the discourses of interviewees E1 and E3 when they stated: "There are many people who talk too much, make much noise, but do not contribute anything. [...] And there it goes; the person comes and [says] that it was he who sponsored [the project]" and "I can prioritize a project that I do not think is a priority just to please". In this way, the sponsor with an opportunist style operates for their benefit, whether or not what they are doing aligns with the company's strategic objectives and other areas.

\section{Conceptual Framework}

The results from the analysis of codes and their relationships were based on the ideas and arguments of each interviewee. This analysis, along with previously published works, allowed us to generate Figure 3, which graphically represents how the sponsor management styles influence the project prioritization process. In addition, we were able to demonstrate how the project's strategic alignment influences the project prioritization process.

The aspects highlighted in each line mainly emerged from the interviewees' statements. As can be seen, each style has a specificity when evaluating the prioritization phase of projects in a given context. While different styles could be evidenced in the same situation, some issues need to be highlighted when applying a management style to project prioritization.

For a better understanding of the landscape of the research results, we also created Table 4. A relevant aspect in this table is that the researched styles influence the project prioritization process and that the lack of strategic alignment and a formal prioritization process stimulate this influence. On the other hand, the post-project evaluation, the investment committee, and the transparent strategic alignment can mitigate this influence when it's harmful.

In addition to this analysis, it is necessary to explain that the influence of each style must be better understood. For example, inappropriate use of bureaucratic style that seeks to rationalize prioritization, even without promoting a strategic alignment of the projects with the company's goals. 


\begin{tabular}{|c|c|c|c|c|c|c|c|}
\hline & Autocratic Style & Bureaucratic Style & Democratic Style & Innovative Style & Negotiator Style & Opportunistic Style & Technocrat Style \\
\hline $\begin{array}{l}\text { Strategic Alignment } \\
\text { of Projects }\end{array}$ & $\begin{array}{l}\text { It can influence more or } \\
\text { less easily depending on } \\
\text { their hierarchical level. }\end{array}$ & $\begin{array}{l}\text { It is easier to prioritize in } \\
\text { context with clear } \\
\text { company objectives. }\end{array}$ & $\begin{array}{l}\text { One can achieve priority by } \\
\text { ensuring the strategic } \\
\text { alignment of projects, but it } \\
\text { takes longer because of the } \\
\text { number of people it } \\
\text { involves. }\end{array}$ & $\begin{array}{l}\text { The degree of influence } \\
\text { will depend on the } \\
\text { strategic objectives of the } \\
\text { company and the } \\
\text { sponsor's ability to make } \\
\text { clear their demand. }\end{array}$ & $\begin{array}{l}\text { Can influence most } \\
\text { frequently. }\end{array}$ & $\begin{array}{l}\text { If the protection is } \\
\text { aligned with the strategy, } \\
\text { and especially with their } \\
\text { own interests, can } \\
\text { prioritize. }\end{array}$ & $\begin{array}{l}\text { Has greater powrer of } \\
\text { influence in technical } \\
\text { projects, but manages to } \\
\text { increase its influence if } \\
\text { associated with the } \\
\text { negotiating style. }\end{array}$ \\
\hline $\begin{array}{l}\text { Lack of } \\
\text { Alignm }\end{array}$ & \begin{tabular}{|l|} 
Can influence depending \\
on their hierarchical level.
\end{tabular} & 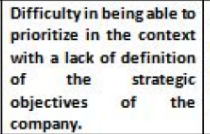 & $\begin{array}{l}\text { Difficulty in being able to } \\
\text { prioritize in the context } \\
\text { with a lack of definition of } \\
\text { the strategic objectives of } \\
\text { the company. }\end{array}$ & $\begin{array}{l}\text { Difficulty in being able to } \\
\text { prioritize in the context } \\
\text { with a lack of definition } \\
\text { of the strategic objectives } \\
\text { of the company. }\end{array}$ & $\begin{array}{l}\text { It can influence most } \\
\text { frequently, mainlydue to } \\
\text { the lack of a clear } \\
\text { strategy. }\end{array}$ & $\begin{array}{l}\text { One may be able to } \\
\text { prioritize to benefit their } \\
\text { own interests. }\end{array}$ & $\begin{array}{l}\text { Has greater power of } \\
\text { influence in technical } \\
\text { projects, but manages to } \\
\text { increase its influence if } \\
\text { associated with the } \\
\text { negotiating style. }\end{array}$ \\
\hline $\begin{array}{l}\text { Lack of Formal } \\
\text { Project Prioritization } \\
\text { Process }\end{array}$ & \begin{tabular}{|l|} 
Can influence depending \\
on their hierarchical level.
\end{tabular} & $\begin{array}{l}\text { Difficulty in being able to } \\
\text { prioritize in context with } \\
\text { lack of process, clinging } \\
\text { to unnecessary } \\
\text { bureaucracy. } \\
\end{array}$ & $\begin{array}{l}\text { Difficulty in being able to } \\
\text { prioritize in context with } \\
\text { lackof process. }\end{array}$ & $\begin{array}{l}\text { The degree of influence } \\
\text { will depend on the } \\
\text { company's strategic } \\
\text { objectives and the } \\
\text { sponsor's ability to make } \\
\text { its demand clear. }\end{array}$ & $\begin{array}{l}\text { Can influence } \\
\text { frequently. }\end{array}$ & $\begin{array}{l}\text { One may be able to } \\
\text { prioritize to benefit their } \\
\text { own interests. }\end{array}$ & $\begin{array}{l}\text { Has greater power of } \\
\text { influence in technical } \\
\text { projects, but manages to } \\
\text { increase its influence if } \\
\text { associated with the } \\
\text { negotiating style. }\end{array}$ \\
\hline $\begin{array}{l}\text { Project Prioritization } \\
\text { Process }\end{array}$ & $\begin{array}{l}\text { It can influence more or } \\
\text { less easily depending on } \\
\text { their hierarchical level. }\end{array}$ & $\begin{array}{l}\text { Easier to meet protocol } \\
\text { requirements in the } \\
\text { prioritization process. }\end{array}$ & $\begin{array}{l}\text { One may be able to } \\
\text { prioritize, but it takes } \\
\text { longer because of the } \\
\text { number of people it } \\
\text { involves. }\end{array}$ & $\begin{array}{l}\text { The degree of influence } \\
\text { will depend on the } \\
\text { company's strategic } \\
\text { objectives and the } \\
\text { sponsor's ability to make } \\
\text { its demand clear. }\end{array}$ & $\begin{array}{l}\text { Can influence most } \\
\text { frequently. }\end{array}$ & $\begin{array}{l}\text { If the protection is } \\
\text { aligned with the strategy } \\
\text { and especially with their } \\
\text { own interests, one can } \\
\text { prioritize. }\end{array}$ & $\begin{array}{l}\text { Has greater power of } \\
\text { influence in technical } \\
\text { projects, but manages to } \\
\text { increase its influence if } \\
\text { associated with the } \\
\text { negotiating style. }\end{array}$ \\
\hline $\begin{array}{l}\text { Investment } \\
\text { Committee }\end{array}$ & \begin{tabular}{|l|} 
It has difficulties in \\
prioritizing through \\
investment committees.
\end{tabular} & \begin{tabular}{|l|} 
Easier compliance with \\
the committee's \\
premises in the \\
prioritization process.
\end{tabular} & $\begin{array}{l}\text { One may be able to } \\
\text { prioritize, but it takes } \\
\text { longer because of the } \\
\text { number of people it } \\
\text { involves. }\end{array}$ & $\begin{array}{l}\text { The degree of influence } \\
\text { will depend on the } \\
\text { company's strategic } \\
\text { objectives and the } \\
\text { sponsor's ability to make } \\
\text { its demand clear. }\end{array}$ & $\begin{array}{l}\text { Not always able to meet } \\
\text { the protocol } \\
\text { requirements of the } \\
\text { process, but may be able } \\
\text { to prioritize influencing } \\
\text { decision-makers. }\end{array}$ & \begin{tabular}{|l|} 
Not always able to meet \\
the protocol \\
requirements of the \\
process, but may be able \\
to prioritize influencing \\
decision-makers if it is for \\
their own benefit. \\
\end{tabular} & $\begin{array}{l}\text { It can meet the protocol } \\
\text { requirements in the } \\
\text { prioritization process. }\end{array}$ \\
\hline $\begin{array}{l}\text { Post-Project } \\
\text { Evaluation }\end{array}$ & $\begin{array}{l}\text { It faces difficulties in } \\
\text { prioritization if the projects } \\
\text { already prioritized do not } \\
\text { reach the intended } \\
\text { objectives. }\end{array}$ & \begin{tabular}{|l|} 
Easier to prove the \\
achievement of the \\
intended objectives.
\end{tabular} & $\begin{array}{l}\text { It can demonstrate the } \\
\text { achievement of the } \\
\text { intended objectives. }\end{array}$ & $\begin{array}{l}\text { One has difficulties in } \\
\text { prioritizing in the context } \\
\text { where it is necessary to } \\
\text { prove the achievement of } \\
\text { the intended objectives. }\end{array}$ & $\begin{array}{l}\text { Faces difficulties in } \\
\text { prioritization if the } \\
\text { projects already } \\
\text { prioritized do not reach } \\
\text { the intended objectives. }\end{array}$ & $\begin{array}{l}\text { Faces difficulties in } \\
\text { prioritization if the } \\
\text { projects already } \\
\text { prioritized do not reach } \\
\text { the intended objectives. }\end{array}$ & $\begin{array}{l}\text { Easier to prove the } \\
\text { achievement of the } \\
\text { intended objectives. }\end{array}$ \\
\hline
\end{tabular}

Table 4. Relationship between the sponsor's managerial styles and project prioritization

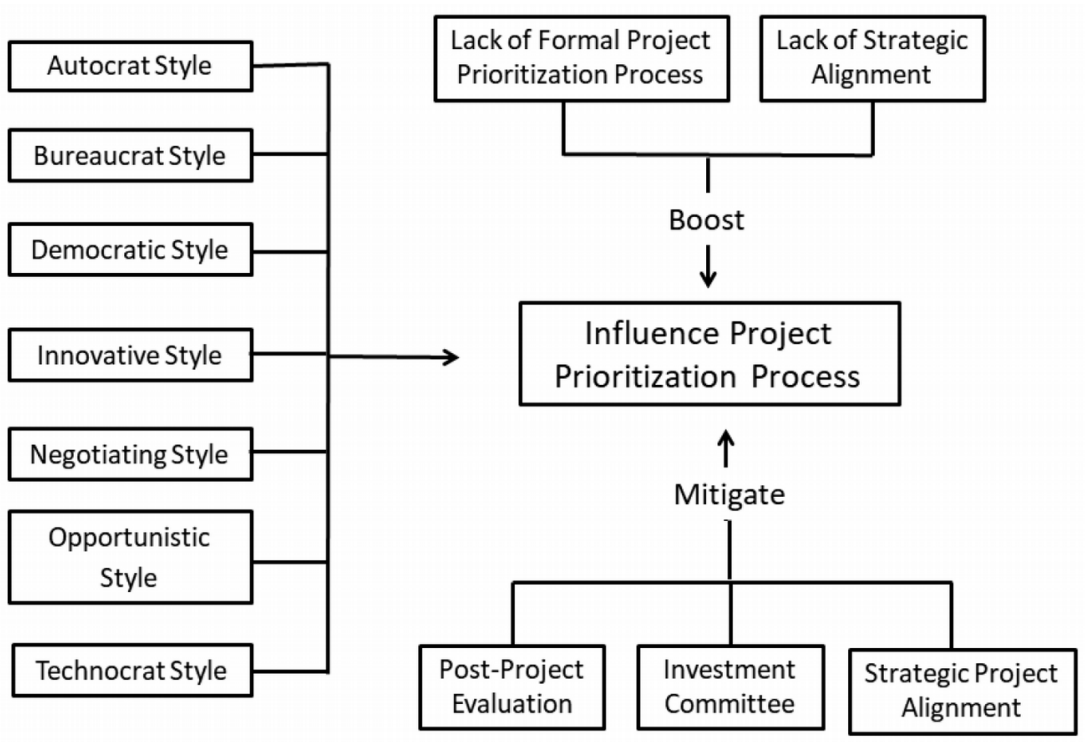

Figure 3. Sponsor's managerial styles influence on project prioritization model

The autocrat management style tends to employ more influence in contexts without a strategic alignment of projects and no clear prioritization processes. In these contexts, the sponsor tends to achieve unilateral prioritization without looking at the company as a whole. It should be pointed out that autocratic sponsors can exercise influence in companies that have a clear strategic alignment of projects. However, in these cases, their power of authority varies depending on their level in the company. This situation occurs because unilateral priorities become scarce in companies with clear project strategic alignment of projects.

The negotiator and opportunist management styles tend to apply influence in the project prioritization process in companies with strategic alignment of projects and established project prioritization processes, as well as in companies that do not have such processes. However, the opportunistic style will give preference to their interests even in companies with clear strategic alignment of projects. Concerning the negotiating style, it tends to exert 
more influence in situations without a clear strategy since it will not need to prove required returns and will depend exclusively on its business attributes.

The technocratic management style tends to exert influence in the project prioritization process in contexts with and without strategic alignment of projects. However, its effectiveness in prioritization is enhanced with negotiating attributes. The negotiation attributes can be obtained by employing interpersonal development or through the participation of other sponsors that can contribute these attributes.

Project prioritization via the top-down mode tends to be used frequently by sponsors with an autocratic management style and this approach is contradictory to the bureaucratic, democratic, and innovative management styles. The negotiator and opportunist management styles can make use of their negotiating attributes to convince high-level executives, which can guarantee the desired prioritization in a top-down manner.

The investment committee and the post-project evaluation are presented as methods to balance the level of influence of the sponsor and avoid prioritizing projects that do not meet the intended objectives of the company. The innovative style tends to be less effective in stable and conservative environments.

\section{Managerial Implications}

This research aims to provide project management practitioners and executives a better understanding of sponsor management styles and project prioritization. Our results showed that the influence exerted by the sponsor can make it possible to prioritize projects through the strategic alignment of projects. Additionally, the same influence can be exercised by the sponsor in companies that lack formal processes for prioritizing projects and strategic alignment. Notably, even in companies where the strategic alignment of projects was evident, the project prioritization was primarily justified by the individual interests of the sponsor, which was herein referred to as the opportunistic style. This observation was particularly evident in the discourses of the interviewees.

Thus, this research demonstrates the importance of the influence exerted by the sponsor has in the early phase of project prioritization. In this context, it is worth highlighting how different styles of sponsor management impact the conduct of the companies. These different approaches were presented in the matrix of management styles in Table 4, and provide executives with possible scenarios and challenges encountered during the project prioritization phase. By demonstrating how each management style influences specific types of companies, decision-makers will be able to choose the best-suited sponsor or develop the skills of the sponsors to meet the needs of the environment.

Another contribution observed in our research is the identification of the investment committee and the post-project evaluation as possible methods to balance the influence exerted by the project sponsor. Based on the results presented herein, the influence exerted by the sponsor is still a reality, however, with these interventions, the company will be more likely to achieve its organizational goals. This situation forces companies to focus on their business strategies, instead of having to spend resources due to the inadequacy of the sponsors' management styles or dissonance in the company's strategic alignment.

\section{Conclusion}

The main factor that motivated this research was to search for knowledge that focused on the sponsor's conduct in the phase of prioritizing projects in companies. At the end of this study, we can conclude that the sponsor's management style influences the projects to be prioritized for development. This result makes it possible to explain a situation that impacts a variety of companies since this relationship was found to occur in companies with different environments, processes, and methods.

In addition to the impact the sponsor's management style has on the project prioritization process, we also would like to emphasize that the lack of awareness about this relationship can lead to failures and losses by the company. Another relevant aspect detected was the lack of clarity and predictability in most of the prioritization processes described by the interviewees. It was commonly reported that project prioritization methods were more likely to be associated with quantitative indicators. Furthermore, the prioritization of top-down projects is less frequent in companies that have a formal and transparent project prioritization process. 
Based on the results presented in this research, it was possible to relate other management styles with their specifics characteristics in the context of project prioritization (Table 4). These results do not intend to define the best or worst management style of the sponsor, but rather contribute to a better understanding of how sponsors with different styles act in different contexts, and how they exert different levels of influence in these environments.

As demonstrated by interviewees' discourses, the negotiator and autocratic sponsor styles have a strong influence on project prioritization. Moreover, based on the professional history of the interviewees these styles were reported with a higher incidence in a variety of industries.

The opportunistic style was primarily mentioned by interviewees E1, E3, and E4. The common thread among these individuals was that they worked at companies that encouraged the departments to compete against each other for financial rewards. Consequently, the projects ended up being a means for achieving the reward. This creates a favorable environment for more ambitious individuals and enables them to play a more active role in labor relations. This fact allows us to infer that companies that promote competition between departments tend to have sponsors with an opportunistic style. Although the interviewees demonstrated a lower-than-expected knowledge about the types of approaches existing in project prioritization processes, we were able to identify commonalities in the incidents. Likewise, it was possible to observe the absence of incidents that demonstrated the application of project prioritization methods in the interviewees' discourses. This fact confirms the interviewees' ignorance on this subject. Additionally, even when they were instigated about the subject, they deviated the course of the discussion.

Thus, this research demonstrates the importance of the influence exercised by the sponsor in the project prioritization phase. Our results provide executives with knowledge about selecting the sponsor with the management style that best aligns with the goals of the company, and provides insights into how specific abilities can be developed to meet the needs of each environment.

Another contribution is the identification of the investment committee and post-project evaluation as possible methods to balance the influence exercised by project sponsors. In this way, the sponsor's influence would continue being exercised but in a way that supports the goals of the company. Thus, companies can focus on their business strategies, instead of having to spend time and money on sponsors that are not aligned with the company's objectives, or the dissonance in the strategic alignment of the company.

Although the interviews were carried out to the point of theoretical saturation, the types of industries, projects and management styles of the sponsors surveyed was limited to the professional background of the interviewees. In this sense, the research was not exhaustive. Notwithstanding the effort to obtain greater details from the interviewees, about the project prioritization methods, this information was lacking in the interviewees' discourses. Unfortunately, it appears as though this issue is not a concern for most project sponsors. Thus, we were unable to obtain the expected amount of information on this topic.

Concerning theoretical contributions, this research demonstrates how the action of the investment committee mitigates the negative influence of sponsors in the project prioritization process. The lack of strategic alignment and formal methods of project prioritization appears to encourage the emergence of opportunistic behaviors from the sponsors. Since the objectivity of these items allows other researchers to capture the same phenomenon, these two aspects can be tested in future studies.

For future research, we suggest a comparative study investigating the relationship between the different management styles of the sponsor and the methods used by companies for project prioritization. We also propose that other researchers focus on the analysis of the influence of sponsor management styles in different phases of portfolio management and project management. Furthermore, we can propose here that (i) there is a positive relationship between the existence of an investment committee and the prioritization of projects that are more aligned with the company's strategy and (ii) the companies with less strategic alignment of projects have opportunistic sponsors. 


\section{Declaration of Conflicting Interests}

The authors declare no potential conflicts of interest with the research, authorship, and/or publication of this article.

\section{Funding}

This study was financed in part by the Coordenação de Aperfeiçoamento de Pessoal de Nível Superior - Brasil (CAPES).

\section{References}

Archer, N.P., \& Ghasemzadeh, F. (1999). An Integrated Framework for Project Portfolio Selection. International Journal of Project Management, 17(4), 207-216. https://doi.org/10.1016/S0263-7863(98)00032-5

Bardhan, I., Kauffman, R., \& Naranpanawe, S. (2010). IT Project Portfolio Optimization: A Risk Management Approach to Software Development Governance. Journal of Research and Development, 54(2), 2:1-2:18. https://doi.org/10.1147/JRD.2009.2039824

Bergamini, C.W. (1994). Liderança: A Administração Do Sentido. RAE - Revista de Administração de Empresas, 34(3), 102-114. https://doi.org/10.1590/S0034-75901994000300009

Bêrni, D.A., \& Fernandez, B.P.M. (2012). Métodos e Técnicas de Pesquisa: Modelando as Ciências Empresariais. São Paulo: Saraiva.

Cha, J., \& Maytorena-Sanchez, E. (2019). Prioritising project management competences across the software project life cycle. International Journal of Managing Projects in Business. https://doi.org/10.1108/IJMPB-11-2017-0145

Chakkol, M., Selviaridis, K., \& Finne, M. (2018). The governance of collaboration in complex projects. International journal of operations \& production management, 38(4), 997-1019. https://doi.org/10.1108/IJOPM-11-2017-0717

Chandler, D.E., \& Thomas, J.L. (2015). Does Executive Sponsorship Matter for Realizing Project Management Value? Project Management Journal, 46(5), 46-61. https://doi.org/10.1002/pmj.21521

Charmaz, K. (2006). Constructing Grounded Theory: A Practical Guide through Qualitative Research. London: Sage.

Cooper, R.G., Easingwood, C.J., Edgett, S., Kleinschmidt, E.J., \& Storey, C. (1994). What Distinguishes the Top Performing New Products in Financial Services. The Journal of Product Innovation Management, 11(4), 281-299. https://doi.org/10.1111/1540-5885.1140281

Cooper, R.G., Edgett, S.J., \& Kleinschmidt, E.J. (2000). New Problems, New Solutions: Making Portfolio Management More Effective. Research Technology Management, 43(2), 1-23.

https://doi.org/10.1080/08956308.2000.11671338

Creswell, J.W. (2010). Projeto de Pesquisa: Métodos Qualitativo, Quantitativo e Misto (3th ed.). Porto Alegre: Artmed.

Dey, P.K. (2004). Analytic hierarchy process helps evaluate project in Indian oil pipelines industry. International Journal of Operations \& Production Management, 24(6), 588-604. https://doi.org/10.1108/01443570410538122

Driver, M.J., Brousseau, K.R., \& Hunsaker, P.L. (1998). The Dynamic Decision Maker: Five Decision Styles for Executive and Business Success. To Excel.

Drucker, P.F., \& Maciariello, J.A. (2008). Management. New York: Collins.

Englund, R.L., Bocero A., \& Bass, J. (2007). Project Sponsorship: Acbieving Management Commitment for Project Success (580-583). Project Management Institute.

French, J.R.P., \& Raven, B. (1959). The Bases of Social Power. Studies of Social Power (150-167).

Friese, S. (2012). Qualitative Data Analysis with ATLAS.Ti. London: SAGE Publications. 
Gemmill, G.R., \& Thamhain, H.J. (1973). The Effectiveness of Different Power Styles of Project Managers in Gaining Project Support. IEEE Transactions on Engineering Management EM, 20(2), 38-44.

https://doi.org/10.1109/TEM.1973.6448421

Gregory, R.W., \& Keil, M. (2014). Blending Bureaucratic and Collaborative Management Styles to Achieve Control Ambidexterity in IS Projects. European Journal of Information Systems, 23(3), 343-356.

https://doi.org/10.1057/ejis.2013.3

Greiner, M.A., Fowler, J.W., Shunk, D.L., Carlyle, W.M., \& McNutt, R.T. (2003). A Hybrid Approach Using the Analytic Hierarchy Process and Integer Programming to Screen Weapon Systems Projects. IEEE Transactions on Engineering Management, 50(2), 192-203. https://doi.org/10.1109/TEM.2003.810827

Henderson, J.C., \& Venkatraman, H. (1993). Strategic Alignment: Leveraging Information Technology for Transforming Organizations. IBM Systems Journal, 32(1), 472-484. https://doi.org/10.1147/sj.382.0472

Hersey, P., \& Blanchard, K.H. (2014). Psicologia para administradores (4th ed.). São Paulo: E.P.U.

Hodgetts, R.M. (1968). Leadership Techniques in the Project Organization. Academy of The Academy of Management Journal, 11(2), 211-219. https://doi.org/10.2307/255258

Idler, B.D., \& Spang, K. (2019). IT project decisions: conclusions and recommendations for corporate practice. International Journal of Managing Projects in Business. https:/ / doi.org/10.1108/IJMPB-04-2018-0082

Kang, J.H., Solomon, G.T., \& Choi, D.Y. (2015). CEOs’ leadership styles and managers' innovative behaviour: Investigation of intervening effects in an entrepreneurial context. Journal of Management Studies, 52(4), 531-554. https://doi.org/10.1111/joms.12125

Karhade, P., Shaw, M.J., \& Subramanyam, R. (2015). Patterns in Information Systems Portfolio Prioritization: Evidence From Decision Tree Induction. MIS Quarterly, 39(2), 413-A12.

https://doi.org/10.25300/MISQ/2015/39.2.07

Kerzner, H. (2017). Project management: A systems approach to planning, scheduling, and controlling. John Wiley \& Sons.

Ketokivi, M., \& Mahoney, J.T. (2016). Transaction Cost Economics as a Constructive Stakeholder Theory. Academy of Management Learning \& Education, 15(1), 123-138. https://doi.org/10.5465/amle.2015.0133

Kirton, M. (1976). Adaptors and Innovators: A Description and Measure. Journal of Applied Psychology, 61(5), 622-629. https://doi.org/10.1037/0021-9010.61.5.622

Kloppenborg, T.J, \& Tesch, D. (2015). How Executive Sponsors Influence Project Success. MIT Sloan Management Review, 56(3), 27-30.

Kloppenborg, T.J., Tesch, D., \& Manolis, C. (2014). Project Success and Executive Sponsor Behaviors: Empirical Life Cycle Stage Investigations. Project Management Journal, 45(1), 9-20. https://doi.org/10.1002/pmj.21396

Kornfeld, B.J., \& Kara, S. (2011). Project portfolio selection in continuous improvement. International Journal of Operations \& Production Management, 31(10), 1071-1088. https:/ / doi.org/10.1108/01443571111172435

Lewis, M.W., Welsh, M.A., Dehler, G.E., \& Green, S.G. (2002). Product development tensions: Exploring contrasting styles of project management. Academy of Management Journal, 45(3), 546-564.

https://doi.org/10.2307/3069380

Lincoln, Y.S., \& Guba, E.G. (1985). Structure Naturalistic Inquiry. London: Sage Publications. https://doi.org/10.1016/0147-1767(85)90062-8

Malach-Pines, A., Dvir, D., \& Sadeh, A., (2009). Project manager-project (PM-P) fit and project success. International Journal of Operations \& Production Management, 29(3), 268-291. ttps://doi.org/10.1108/01443570910938998

Maylor, H., \& Turner, N. (2017). Understand, reduce, respond: project complexity management theory and practice. International Journal of Operations \& Production Management, 37(8), 1076-1093. https://doi.org/10.1108/IJOPM-05- 
Mintzberg, H., Ahlstrand B., \& Lampel, J. (2010). Safári de Estratégia (2nd ed.). Porto Alegre: Bookman.

Morgan, G. (2011). Imagens Da Organização (2nd ed.). São Paulo: Atlas.

Morris, P.W., \& Jamieson, A. (2005). Moving from corporate strategy to project strategy. Project Management Journal, 36(4), 5-18. https://doi.org/10.1177/875697280503600402

Müller, R., \& Turner, R. (2007). The influence of project managers on project success criteria and project success by type of project. European Management Journal, 25(4), 298-309. https://doi.org/10.1016/j.emj.2007.06.003

Olmedo-Cifuentes, I., \& Martínez-León, I.M. (2014). Influence of Management Style on Employee Views of Corporate Reputation. BRQ Business Research Quarterly, 17(4), 223-241. https://doi.org/10.1016/j.brq.2013.08.001

Padovani, M., Carvalho, M.M., \& Muscat, A.R.N. (2010). Seleção e Alocação de Recursos Em Portfólio de Projetos: Estudo de Caso No Setor Químico. Gestão \& Produção, 17(1), 157-180. https://doi.org/10.1590/S0104530X2010000100013

Petro, Y., \& Gardiner, P. (2015). An Investigation of the Influence of Organizational Design on Project Portfolio Success, Effectiveness and Business Efficiency for Project-Based Organizations. International Journal of Project Management, 33(8), 1717-1729. https://doi.org/10.1016/j.ijproman.2015.08.004

Pinto, L.F.V., Nossa, V., \& Teixeira, A. (2015). Inovação: Estratégia de Competitividade e Sustentabilidade Na Gestão Hospitalar. Contextus - Revista Contemporânea de Economia e Gestão, 13(3), 216-243. https://doi.org/10.19094/contextus.v13i3.750

PMI (2017). Um Guia Do Conhecimento Em Gerenciamento de Projetos (PMBoK) (6th ed.). Project Management Institute, Inc.

Ramos, P., Mota, C., \& Corrêa, L. (2016). Exploring the Management Style of Brazilians Project Managers. International Journal of Project Management, 34(6), 902-913. https://doi.org/10.1016/j.ijproman.2016.03.002

Saldaña, J. (2012). The Coding Manual for Qualitative Researchers (2nd ed.). SAGE Publications.

Santhanam, R., \& Kyparisis, J. (1995). A Multiple Criteria Decision Model for Information System Project Selection. Computers \& Operations Research, 22(8), 807-818. https://doi.org/10.1016/0305-0548(94)00069-K

Shenhar, A.J. (1998). From Theory to Practice: Toward a Typology of Project-Management Styles. IEEE Transactions on Engineering Management, 45(1), 33-48. https:/ / doi.org/10.1109/17.658659

Shenhar, A.J., \& Dvir, D. (2010). Reinventando Gerenciamento de Projetos. São Paulo: M. Books.

Shenhar, A.J., Dvir, D., Levy, O., \& Maltz, A.C. (2001). Project Success: A Multidimensional Strategic Concept. Long Range Planning, 34(6), 699-725. https://doi.org/10.1016/S0024-6301(01)00097-8

Shollo, A., Constantiou, I., \& Kreiner, K. (2015). The Interplay between Evidence and Judgment in the IT Project Prioritization Process. Journal of Strategic Information Systems, 24(3), 171-188. https://doi.org/10.1016/j.jsis.2015.06.001

Silva, A.B., Godoi C.K., \& Melo, R.B. (2010). Pesquisa Qualitativa em Estudos Organizacionais. São Paulo: Saraiva.

Standish Group (2014). The Standish Group: The Chaos Report. Project Smart, 16.

Tabassi, A.A., Abdullah, A., \& Bryde, D.J. (2019). Conflict Management, Team Coordination, and Performance Within Multicultural Temporary Projects. Project Management Journal, 50(1), 101-114.

https://doi.org/10.1177/8756972818818257

Taskinen, T., \& Smeds, R. (1999). Measuring change project management in manufacturing. International Journal of Operations \& Production Management, 19(11), 1168-1187. https:/ / doi.org/10.1108/01443579910291078

Tsai, W.H., Leu, J.D., Liu, J.Y., Lin, S.J., \& Shaw, M.J. (2010). A MCDM Approach for Sourcing Strategy Mix Decision in IT Projects. Expert Systems with Applications, 37(5), 3870-3886.

https://doi.org/10.1016/j.eswa.2009.11.031

Turner, J.R. (2009). The Handbook of Project Based Management: Leading Strategic Change in Organizations. McGraw-Hill. 
Turner, R.J., Müller, R., \& Dulewicz, V. (2009). Comparing the leadership styles of functional and project managers. International Journal of Managing Projects in Business, 2(2), 198-216. https:/ / doi.org/10.1108/17538370910949266

Vieira, L.J.M., \& Costa, S.G. (2013). Liderança No Judiciário: O Reconhecimento de Magistrados Como Líderes. Revista de Administração Pública, 47(4), 927-948. https:/ / doi.org/10.1590/S0034-76122013000400006

Williamson, O.E. (1996). The mechanisms of governance. Oxford University Press.

Wilson, K.B., Bhakoo, V., \& Samson, D. (2018). Crowdsourcing: A contemporary form of project management with linkages to open innovation and novel operations. International Journal of Operations \& Production Management, 38(6), 1467-1494. https://doi.org/10.1108/IJOPM-12-2016-0753

Xia, W., \& Lee, G. (2005). Complexity of Information Systems Development Projects. Journal of Management Information Systems, 22(1), 45-83. https://doi.org/10.1080/07421222.2003.11045831

Zhu, F., Wang, L., Yu, M., Müller, R., \& Sun, X. (2019). Transformational leadership and project team members’ silence: the mediating role of feeling trusted. International Journal of Managing Projects in Business.

https://doi.org/10.1108/IJMPB-04-2018-0090

Zimmer, P., Iata, C.M., Souza, J.A., \& Cunha, C.J.C.A. (2017). Fatores Determinantes Para o Desempenho Em Inovação Das Indústrias Optantes Lucro Real Em Santa Catarina. Revista Gestão \& Tecnologia, 17(3), 191-216. https://doi.org/10.20397/2177-6652/2017.v17i3.1085

Zwikael, O., Meredith, J.R., \& Smyrk, J. (2019). The responsibilities of the project owner in benefits realization. International Journal of Operations \& Production Management, 39(4), 503-524. https://doi.org/10.1108/IJOPM-02-20180086

Journal of Industrial Engineering and Management, 2020 (www.jiem.org)

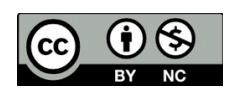

Article's contents are provided on an Attribution-Non Commercial 4.0 Creative commons International License. Readers are allowed to copy, distribute and communicate article's contents, provided the author's and Journal of Industrial Engineering and Management's names are included. It must not be used for commercial purposes. To see the complete license contents, please visit https://creativecommons.org/licenses/by-nc/4.0/. 